\title{
ECONOMIC DIMENSIONS OF SUSTAINABLE TOURISM IN BULGARIA
}

\author{
D. Doncheva* \\ Department of Economics, Faculty of Economics, Trakia University, Stara Zagora, Bulgaria
}

\begin{abstract}
The tourism industry is one of the key sectors for economic growth. In the context of expansion and development of the tourism sector worldwide, assessment of its sustainability in the regions or countries becomes an important goal of strategic planning, main tool for maintaining a balance between current and future prospects for their development, especially in the areas with a tourism-based economy. Sustainable tourism can maintain the balance between economic development and environmental protection. The article aims to analyze the main economic dimensions of sustainable tourism in Bulgaria and to highlight opportunities for its development. The analyzed data of the selected indicators for the evaluation of sustainable development of Bulgarian tourism demonstrated quite stable development.
\end{abstract}

Key words: sustainable development, economic benefits, tourism destination, sustainable tourism indicators

\section{INTRODUCTION}

The tourism industry is one of the key sectors for economic growth. In the context of expansion and development of the tourism sector worldwide, assessment of its sustainability in the regions or countries becomes an important goal of strategic planning, main tool for maintaining a balance between current and future prospects for their development, especially in the areas with a tourism-based economy. Now sustainable development and sustainability are key elements of the debate on how to use tourism's natural and social resources to gain economic benefits (1). Sustainable tourism can maintain the balance between economic and sociocultural development and environmental protection.

The major drivers of sustainability in all tourism industries remain the competitiveness and profitability (2). Bulgarian tourism sector faces the challenge of increasing its competitiveness and economic performance

\footnotetext{
*Correspondence to: Dora Doncheva, Department of Economics, Faculty of Economics, Trakia University, Stara Zagora, Bulgaria, 042/ 699 428, e-mail: dora.doncheva@uni-sz.bg
}

while at the same time adopting and implementing the idea of sustainable development, with the understanding that in the near future, competitiveness will depend almost entirely on sustainability (3).

Today, improving economic efficiency and maximizing economic performance by optimizing the use of natural and social resources is one of the foundations of the new Sustainable Development Agenda 2030 of the United Nation. Bulgaria is committed to the implementation of the principles of sustainable development at national level and the implementation of this document (4), which sets 17 Sustainable Development Goals (SDGs). Tourism has the potential to contribute, directly or not, to all of these goals but three of them are those that are particularly related to the sustainable tourism. The Ministry of Tourism is designated as responsible for the implementation of two sub-goals and has a role in the realization of a third sub-goals as follows (5-6):

- SDG 8. Promote sustained, inclusive and sustainable economic growth, employment and decent work for all; sub-goal 8.9 - by 2030, devise and implement policies to promote sustainable tourism that creates jobs and promotes local culture and products; 
SDG 12 - Ensure sustainable consumption and production patterns; sub-goal $12 \mathrm{~b}$ - develop and implement tools to monitor sustainable development impacts for sustainable tourism that creates jobs and promotes local culture and products;

SDG 6 - Ensure availability and sustainable management of water and sanitation for all; sub-goal 6.4 - by 2030 , substantially increase water-use efficiency across all sectors and ensure sustainable withdrawals and supply of freshwater to address water scarcity and substantially reduce the number of people suffering from water scarcity.

\section{Tourism Strategy 2030: focus on sustainability}

The growth of tourism in recent years has demonstrated its importance as an activity that generates wealth, employment and the development of new economic activities. However, this growth has brought important challenges in terms of making the development model compatible with local communities and with the Sustainable Development Goals (7). In this context, governments and tourism stakeholders demand to develop the tourism strategies and policies that relies on the principles of sustainability.

In Bulgaria, in the recent year the tourism registered positive results that reinforce its capacity to generate more revenue and employment and to extend the activity throughout the year and all over the country. It is recognized, therefore, that tourism has the capacity to be a sustainable activity throughout the year and to add value to local communities and the country as a whole.

The Bulgarian Government launched in 2014 and updated in 2017 the National Strategy for Sustainable development of Tourism 20142030, which defines the vision for the Bulgarian tourism industry for the next 15 years: "To make Bulgaria a year-long destination whose development is based on the principles of sustainability - optimal use of resources, respect for the socio-cultural authenticity of local communities, ensuring reliable economic activity and an even distribution of socio-economic benefits" (8). As Bulgaria is in its early stages of development of sustainable tourism the responsible authorities have to provide the necessary conditions for the sustainable development of the sector by balancing the tourists' well-being and local communities, the needs of the natural and cultural environment and the development and competitiveness of the destination and business (9).

The Bulgarian National Tourism Strategy 2030 establishes four strategic pillars:

To create a favorable environment and business area for developing Sustainable Tourism;

To develop a competitive Tourism sector;

To promote Bulgaria and successfully positioning the country in the world tourism market as an attractive destination;

To balance the development of tourism areas.

\section{The importance of Tourism's economic sustainability performance and its measurement}

Maximization of economic benefits, increasing of competitiveness and growth are the main objectives of managers of tourism businesses. Achieving these goals require the use of proper economic sustainable indicator that will allow managers and other decision-making stakeholders to measure economic sustainability and think more strategically.

The importance of sustainability in tourism and its measurement and interpretation is highlighted by many authors throughout the literature (10-15). In addition, the European Union (16), World Tourism Organisation (WTO) (17), the European Environment Agency (EEA) (18) and the Organization for Economic Co-operation and Development (OECD) (19) have issued a document describing sustainability indicators and their measurement in all three pillars - economic, environmental and social. These measurements explore and highlight the role of tourism of some key areas, such as: inclusive and sustainable economic growth; social inclusiveness, employment and poverty reduction; resource efficiency, environmental protection and cultural values, diversity and heritage.

As mentioned earlier, the aim of sustainable development is to incorporate an environmental perspective through economic policy. That concept became the environmental protection a key issue. Tourism has enormous impact on the environment and environment is often considered as a major pull factor for the tourism as the quality of nature is an essential part of natural attraction as far as tourists' 
demand is concerned (20). This is the reason many tourism units to focus on environmental sustainability preservation which can bring economic savings to them in terms of water, electricity, etc. However, the economic sustainability should be put above social and environmental sustainability and incorporate into decision-making process due to overall economic impact of tourism sectors accommodation, food and beverage, transport and tourism agencies, have on the national economy. For this reason, economic performance is and should be taken as the most important of all three pillars (21).

The economic dimensions of sustainable tourism cover overnight stays, bed occupancy, tourism receipts and expenditures, contribution of the tourism to the country's GDP and employment; tourism establishments participating in tourism value chain, tourism's investment and etc.

These indicators should be regularly monitored on national and regional level.

\section{MATERIALS AND METHODS}

UNWTO defines Sustainable tourism as a form of tourism which meet the needs of tourists, the tourism industry, and host communities today without compromising the ability of future generations to meet their own needs (22). In this context, the sustainable tourism should make more optimal use of environmental resources, respect socio-cultural authenticity of host communities and ensuring viable, long-term economic operations, providing fairly distributed socio-economic benefits among all stakeholders.

The above-mentioned goals for making tourism more sustainable forms a complex economic activity that face a set of economic, environmental and social challenges, which require adequate system of indicators for measurement and management of sustainable tourism.

There are several systems for measuring sustainable tourism proposed by some governmental bodies and country. Sustainable tourism indicators presented in the background material were compiled in studies developed by organizations as: United Nations Statistics Division (UNSD), the Statistical Office of the European Communities (EUROSTAT), the Organisation for Economic Co-operation and Development (OECD), the World Tourism Organization (UNWTO) and the European
Environment Agency (EEA). These organizations developed a harmonised system of tourism satellite accounts (TSA:RMF 2008) (23) and its update throughout the years. It is the internationally recognised framework for measuring tourist activity and the importance of tourism to national or regional economies and can tell us how much tourism contributes to an economy and how many jobs it creates.

The TSA framework consists of 10 tables relating mostly to the demand side and some of them relating to supply side of the sustainable tourism based on macroeconomic variables such as gross value added, gross domestic product, employment.

In 2017 UNWTO launched the Statistical Framework for Measuring Sustainable Tourism initiative (MST Framework), which aims to integrate current economic focused frameworks and environmental, social and cultural dimensions (24).

In addition to the indicators proposed in the TSA:RMF 2008, this study also uses some of the indicators proposed in the DPSIR framework, in terms of the economic dimensions of sustainable tourism. DPSIR is an abbreviation for Driving forces, Pressure, State, Impact and Responses framework, advocated by the Environment Agency (based on the OECD Pressure State Response (PSR) model) allows to be identified some principal interactions between tourism and the environment (25).

The two frameworks were chosen due to allowing data and official statistics from different sources about various dimensions of sustainable tourism to be integrated in them. This provide an information that could be used for monitoring, evaluation, assessment, modelling and projections - the important activity for decision-making progress.

Data used in the various analyzes in the study were collected from different official statistics as: The System of National Accounts (SNA) (26); National Statistical Institute (NSI) (27); Infostat (28); The World Bank (29); Eurostat (30); OECD.stat (31); World Travel and Tourism Council (WTTC) (32). The reference period covers 2008-2018, the period after the accession of Bulgaria to the European Union and recovery after the World economic crisis from 2008 and make a review of ten years forecast. 


\section{RESULTS}

This section is separated into four parts Tourism in the Economy, Tourism demand, Tourism supply and Driving Forces for Sustainable Tourism.

\section{Tourism in the Economy}

Tourism in Bulgaria is a priority sector as it contributes to sustainable development, protection of nature, prosperity of local communities, and economic growth (33). According to WTTC in 2018 tourism directly contributed $3.11 \%$ of GDP and generated $3 \%$ of total employment. The total impact of tourism (including indirect and induced) was estimated to represent $11.71 \%$ of GDP and 11 $\%$ of employment. WTTC is expected that in 2019 the Tourism's direct contribution to GDP will grow by $2.28 \%$ and generated jobs directly will remain $3 \%$ of total employment. Tourism sector is important for economic growth in Bulgaria as the Accommodation and Food service activities form $12.11 \%$ of total value added (according SNA) and total tourism's contribution to value added of 28.25 $\%$ in 2017. Related to the investments in tourism, the total tourism gross fixed capital formation forms $7.39 \%$ of total investment in 2018, an increase by $9.04 \%$ compared to 2017 (WTTC).

In 2018, according WTTC the total international tourism receipts were 8.37 billion BGN, the expenditures for outgoing tourism were 3.73 billion BGN resulting in net tourism revenues of 4.64 billion BGN. Thus, tourism contributed to 12.3 percent of the total export of Bulgaria in 2018.

\section{Tourism Demand}

Bulgarian Tourism shown a steady trend towards increasing the number of nights spent in the country - both Bulgarians and foreigners in reference period (2008-2018), which established the country as a favorable tourist destination. Tourism of the country is dominated by holiday, transit visitors and ones visiting family and friends. The part of visitors that are coming by professional purpose (one of every seven) is growing every year.

In 2018, Bulgaria received 12.4 million international arrivals (inbound tourists), which represents an annual increase of $6.66 \%$ over 2017 and $45 \%$ over 2008 (Table 1). There was a growth of $5.49 \%$ in the number of holiday visits compared to 2017 and $21.8 \%$ over 2008. Business visitors totaled 1.7 million, an increase of $10.6 \%$ compared to 2017 and remarkable growth by $313 \%$ over 2008. That offer an opportunity for developing of an alternative form of tourism business/professional tourism. International arrivals spent a total of 17.75 million nights in all means of accommodation (over $66 \%$ of all nights spent), up nearly $4 \%$ on the previous year and more than 50\% compared to 2008 . The Balkans countries continue to be the top markets for inbound tourism, accounting for 53 $\%$ of international arrivals. The top five inbound markets are Romania (2 million), Turkey (1.5 million), Greece (1.3 million), Germany (1 million) and Republic of North Macedonia (609 591).

Projections set out in the National Strategy for Sustainable Tourism Development in the Republic of Bulgaria 2014-2030 (approved in January 2018) forecasts that the number of nights spent in accommodation establishment by foreigners will growth to 1503.1 thousand in 2020, 1675.8 thousand in $2025,1868.5$ thousand in 2030. The figures of forecast for nights spent by Bulgarians are 847.4 thousand in 2020, 982.4 thousand in 2025 and 1138.9 thousand in 2030. The annual same-day visits are expected to rise to 247.7 thousand in 2030 . It is important to note that Bulgaria tends to attract lower-middle-income and older visitors. According to data from national statistics, in 2018 the median age of the Bulgarian population was 43.8 years and the age of domestic tourists is tending to rise in the future. This is forecast that international tourists are tending to get even older, mainly because of predominantly lower cost of Bulgarian tourist product.

More than 90 percent of international tourists stay in accommodation establishments on the coast in July and August or in mountain resorts in December.

In 2018 the number of international departures accounted almost 6.7 million, an increase of $7.56 \%$ compared to 2017 and $16.96 \%$ more than 2008. The top destinations for outbound tourism in 2018 (see table 1) are Turkey (1.5 million), Greece (1.4 million), Romania (523 058), Serbia (493950) and Republic of North Macedonia (416448). 
Table 1. Tourism demand of Bulgaria for period of 2008-2018

DONCHEVA D.

\begin{tabular}{|c|c|c|c|c|c|c|}
\hline Forms of tourism & 2008 & 2012 & 2017 & 2018 & $\begin{array}{l}\text { Growth } \\
\text { 2017/ } \\
\text { 2018, \% }\end{array}$ & $\begin{array}{l}\text { Growth } \\
\text { 2008/ } \\
2018, \%\end{array}$ \\
\hline $\begin{array}{l}\text { Domestic tourism (total trips } \\
\text { - number) }\end{array}$ & 9292000 & 9663000 & 12754345 & 12985609 & 1.81 & 39.75 \\
\hline Tourists (overnight visitors) & 6493000 & 6801000 & 8948529 & 9096088 & 1.65 & 40.09 \\
\hline $\begin{array}{l}\text { Excursionists (same-day } \\
\text { visitors) }\end{array}$ & 2799000 & 2862000 & 3805816 & 3889521 & 2.20 & 38.96 \\
\hline $\begin{array}{l}\text { Night spent in all types of ac- } \\
\text { commodations }\end{array}$ & 6493386 & 6800598 & 8948529 & 9096088 & 1.65 & 40.08 \\
\hline $\begin{array}{l}\text { Inbound tourism (total } \\
\text { international arrivals - } \\
\text { number) }\end{array}$ & 8533000 & 8867000 & 11596167 & 12368363 & 6.66 & 44.95 \\
\hline Tourists (overnight visitors) & 5780000 & 6541000 & 8883000 & : & : & : \\
\hline $\begin{array}{l}\text { Excursionists (same-day } \\
\text { visitors) }\end{array}$ & 2753000 & 2326000 & 2713167 & $:$ & $:$ & : \\
\hline \multicolumn{7}{|l|}{ Top markets } \\
\hline Germany & 759660 & 784678 & 1046219 & 1063502 & 1.65 & 40.00 \\
\hline Greece & 881458 & 1087260 & 1272997 & 1290313 & 1.36 & 46.38 \\
\hline Romania & 1769194 & 1468179 & 1943436 & 2035606 & 4.74 & 15.06 \\
\hline Republic of North Macedonia & 323400 & 424182 & 583026 & 609591 & 4.56 & 88.49 \\
\hline Turkey & 1116680 & 984212 & 1437276 & 1534809 & 6.79 & 37.44 \\
\hline $\begin{array}{l}\text { Night spent in all types of } \\
\text { accommodations }\end{array}$ & 11802017 & 13451440 & 17105567 & 17748925 & 3.76 & 50.39 \\
\hline $\begin{array}{l}\text { Outbound tourism (total in- } \\
\text { ternational departures - } \\
\text { number) }\end{array}$ & 5727000 & 3758000 & 6227623 & 6698526 & 7.56 & 16.96 \\
\hline Tourists (overnight visitors) & 5727000 & 3758000 & 6227623 & 6698526 & 7.56 & 16.96 \\
\hline \multicolumn{7}{|l|}{ Top destinations } \\
\hline Greece & 1709510 & 789842 & 1341192 & 1402560 & 4.58 & -17.96 \\
\hline Romania & 481564 & 318112 & 480980 & 523058 & 8.75 & 8.62 \\
\hline Republic of North Macedonia & 346384 & 362021 & 396450 & 416448 & 5.04 & 20.23 \\
\hline Serbia & 485310 & 301623 & 462953 & 493950 & 6.70 & 1.78 \\
\hline Turkey & 1227189 & 1091214 & 1311252 & 1515894 & 15.61 & 23.53 \\
\hline
\end{tabular}

Source: own calculation based on data from OECD.stat; NSI, Infostat; the World bank

: - does not apply

\section{Tourism Supply}

According to NSI in 2018 the number of accommodation establishment in Bulgaria were 3458 (Figure 1) with a total bed-places of 335597 , an increase of $7.5 \%$ for properties and $21 \%$ more bed-places than 2008. About $50 \%$ of them are located in regions with coastal areas - South-East (29\%) and NorthEast $(21 \%)$. This results in strong dependence of Bulgarian tourism on the seasons.
However, in the last years from reference period, there is 36 percent increase in establishments in South-West region and relatively stable number of ones in Southcentral region. This characterized the new opportunities for development of alternative forms of tourism, e.g. cultural, historical and business tourism. 


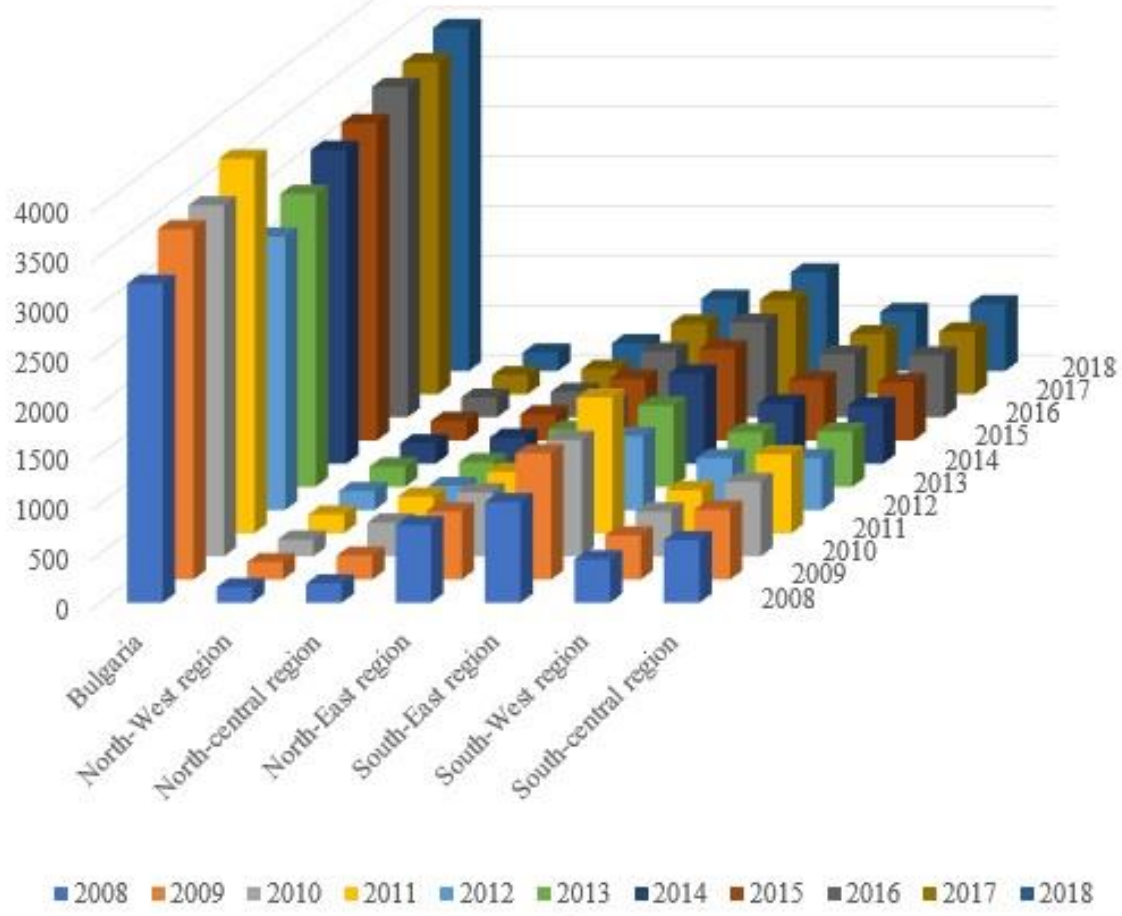

Figure 1. Accommodation establishment by statistical zones and region (NUTS 2) 2008-2018, number Source: Own calculation based on data from NSI, Infostat

The latest trends in Bulgarian tourism after the accession of the country to the EU is part of the global tourism trend. The growing free movements of people due to globalization and internationalization reflect to increased tourist flow in last ten years. That results in the products supplied by tourism-related industries. It is noticeable that main part of tourism industries revenue is formed by inbound expenditure (Table 2).

Table 2. Tourism expenditures by form of tourism and main tourism industries for the period 20082018, million BGN

\begin{tabular}{|c|c|c|c|c|c|c|c|c|c|c|}
\hline \multirow[b]{2}{*}{ Year } & & \multicolumn{8}{|c|}{ A. Consumption products } & \multirow[b]{2}{*}{ Total } \\
\hline & $\begin{array}{l}\text { Form of } \\
\text { tourism }\end{array}$ & $\begin{array}{c}\text { A.1 } \\
\text { Tourism } \\
\text { characteri } \\
\text { stic } \\
\text { products }\end{array}$ & $\begin{array}{c}1 . \\
\text { Accommo- } \\
\text { dation } \\
\text { services }\end{array}$ & $\begin{array}{c}2 . \\
\text { Food and } \\
\text { beverage } \\
\text { serving } \\
\text { services }\end{array}$ & $\begin{array}{c}3 . \\
\text { Passenger } \\
\text { transport } \\
\text { services }\end{array}$ & $\begin{array}{c}4 . \\
\text { Travel } \\
\text { agencies } \\
\text { and other }\end{array}$ & $\begin{array}{c}5 . \\
\text { Cultural } \\
\text { services }\end{array}$ & $\begin{array}{c}6 . \\
\text { Sports } \\
\text { and } \\
\text { recreatio } \\
\text { nal } \\
\text { services } \\
\end{array}$ & $\begin{array}{c}\text { A.2 } \\
\text { Other } \\
\text { consumpti } \\
\text { on } \\
\text { products }\end{array}$ & \\
\hline \multirow{3}{*}{ 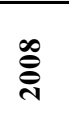 } & Domestic & 382.74 & 81.03 & 105.31 & 126.45 & 5.19 & 59.74 & 5.02 & 110.62 & 493.36 \\
\hline & Inbound & 4462.45 & 1368.27 & 1743.27 & 708.71 & & 582.42 & 59.78 & 1866.95 & 6329.4 \\
\hline & Outbound & 1371.99 & 297.09 & 564.5 & 384.47 & 0 & 102.94 & 22.99 & 2076.51 & 3448.5 \\
\hline \multirow{3}{*}{ ำ } & Domestic & 951.03 & 238.24 & 324.26 & 282.9 & 14.34 & 76.8 & 14.49 & 93.47 & 1044.5 \\
\hline & Inbound & 4278.73 & 1300.36 & 1678.48 & 729.27 & 0 & 506.06 & 64.56 & 1969.26 & 6247.99 \\
\hline & Outbound & 926.42 & 182.01 & 474.95 & 171.68 & 0 & 76.09 & 21.69 & 748.77 & 1675.19 \\
\hline \multirow{3}{*}{ ำ } & Domestic & 1314.76 & 385.33 & 370.41 & 340 & 80.48 & 108.9 & 29.64 & 123.09 & 1437.85 \\
\hline & Inbound & 5653.51 & 1537.13 & 2431.76 & 817.62 & 0 & 656 & 211 & 1668.19 & 7321.7 \\
\hline & Outbound & 2562.91 & 691.75 & 888.17 & 734.52 & 50.84 & 120.34 & 77.29 & 321.13 & 2884.04 \\
\hline \multirow{3}{*}{ 궁 } & \begin{tabular}{|l|} 
Domestic \\
\end{tabular} & $\mathbf{x}$ & $\mathrm{x}$ & $\mathrm{x}$ & $\mathrm{x}$ & $\mathrm{x}$ & $\mathrm{x}$ & $\mathrm{x}$ & $\mathbf{x}$ & 1355.19 \\
\hline & Inbound & $\mathbf{x}$ & $\mathrm{x}$ & $\mathrm{x}$ & $\mathrm{x}$ & $\mathrm{x}$ & $\mathrm{x}$ & $\mathrm{x}$ & $\mathbf{x}$ & 7880.92 \\
\hline & Outbound & $\mathbf{x}$ & $\mathrm{x}$ & $\mathrm{x}$ & $\mathrm{x}$ & $\mathrm{x}$ & $\mathrm{x}$ & $\mathrm{x}$ & $\mathbf{x}$ & 3448.71 \\
\hline \multirow{3}{*}{$\stackrel{\infty}{\sim}$} & Domestic & $\mathbf{x}$ & $\mathrm{x}$ & $\mathrm{x}$ & $\mathrm{x}$ & $\mathrm{x}$ & $\mathrm{x}$ & $\mathrm{x}$ & $\mathbf{x}$ & 1536.43 \\
\hline & Inbound & $\mathbf{x}$ & $\mathrm{x}$ & $\mathrm{x}$ & $\mathrm{x}$ & $\mathrm{x}$ & $\mathrm{x}$ & $\mathrm{x}$ & $\mathbf{x}$ & 8370.33 \\
\hline & Outbound & $\mathbf{x}$ & $\mathrm{x}$ & $\mathrm{x}$ & $\mathrm{x}$ & $\mathrm{x}$ & $\mathrm{x}$ & $\mathrm{x}$ & $\mathbf{x}$ & 3730.72 \\
\hline
\end{tabular}

Source: own calculation based on data from NSI, WTTC $\mathrm{x}$ does not apply. 
In 2018 foreigners spending were $6.21 \%$ more than 2017 and over $32 \%$ more than 2008 . About $70-75 \%$ of inbound expenditure were spent for tourism characteristic products -33 $\%$ for food and beverage, $21 \%$ for accommodation, $11 \%$ for transport, $9 \%$ for cultural services and over $20 \%$ for other consumption products.

In term of the expenditures of resident in the country and abroad it is shown that they spent primary for accommodation and food (Table 2) in both - Bulgaria and abroad, spent more money for cultural services in abroad.

According to WTTC it is expected in 2019 inbound tourism expenditure grow by $4.27 \%$ to 8.7795 billion BGN and this is forecast to rise to 15.3437 billion BGN (13.06 \% of export) in 2028. In relation to domestic and outbound tourism expenditures it is expected to increase to 1.6512 and 4.0293 billion BGN in
2019, respectively. This is forecast that expenditure of two forms of tourism will slightly grow in the next ten years to 2.613 billion BGN (1.52\% of GDP) for domestic tourism and 6.02 billion BGN $92.67 \%$ of GDP) for outbound tourism.

At a macro-economic level, the growth of tourism in last ten years was found that resulted in an increase of the tourism's contribution to the development of the country. In 2016, $15.19 \%$ enterprises from Bulgarian's non-financial business economy belonged to the tourism industries (Table 3). These 336 041 enterprises employed 1.9 million persons. Enterprises in industries with tourism related activities accounted for $13.77 \%$ of the persons employed in the non-financial business economy and $40.25 \%$ of persons employed in the services sector.

Table 3. Main economic indicators for the tourism industries of Bulgaria, 2008/2016

\begin{tabular}{|c|c|c|c|c|c|c|c|c|}
\hline \multirow{2}{*}{$\begin{array}{l}\text { Indicators } \\
\text { Sectors/Time }\end{array}$} & \multicolumn{2}{|c|}{$\begin{array}{l}\text { Number of } \\
\text { enterprises }\end{array}$} & \multicolumn{2}{|c|}{$\begin{array}{l}\text { Turnover } \\
\text { (million euro) }\end{array}$} & \multicolumn{2}{|c|}{$\begin{array}{l}\text { Value added at } \\
\text { factor cost } \\
\text { (million euro) }\end{array}$} & \multicolumn{2}{|c|}{$\begin{array}{l}\text { Persons employed } \\
\text { (number) }\end{array}$} \\
\hline & 2008 & 2016 & 2008 & 2016 & 2008 & 2016 & 2008 & 2016 \\
\hline $\begin{array}{l}\text { Total non-financial } \\
\text { business economy }\end{array}$ & 276717 & 336041 & 106066 & 120068 & 18025 & 24803 & 2064627 & 1961520 \\
\hline Total services ${ }^{(2)}$ & 98336 & 141787 & 15064 & 20165 & 5545 & 8286 & 562702 & 671077 \\
\hline Total tourism industries ${ }^{(3)}$ & 39705 & 51048 & 5748 & 7814 & 1548 & 2400 & 243296 & 270081 \\
\hline $\begin{array}{l}\text { Tourism industries } \\
\text { (mainly tourism })^{(4)}\end{array}$ & 4252 & 6729 & 1336 & 1854 & 353 & 555 & 45430 & 50507 \\
\hline $\begin{array}{l}\text { Tourism industries (par- } \\
\text { tially tourism) }{ }^{(5)}\end{array}$ & 35453 & 44319 & 4412 & 5959 & 1195 & 1845 & 197866 & 219574 \\
\hline Transport related (total) & 15003 & 19242 & 3760 & 4789 & 911 & 1389 & 104914 & 116115 \\
\hline $\begin{array}{l}\text { Land transport and tran- } \\
\text { sport via pipelines (H49) }\end{array}$ & 14916 & 19108 & 3046 & 4331 & 758 & 1304 & 96797 & 112406 \\
\hline Water transport (H50) & 49 & 86 & 310 & 87 & 107 & 30 & 5451 & 1633 \\
\hline Air transport (H51) & 38 & 48 & 404 & 371 & 47 & 55 & 2666 & 2076 \\
\hline Accommodation (I55) & 2992 & 4767 & 606 & 934 & 269 & 441 & 36943 & 42207 \\
\hline $\begin{array}{l}\text { Food and beverage (total) } \\
\text { (I56) }\end{array}$ & 19180 & 22265 & 885 & 1294 & 240 & 377 & 91979 & 100578 \\
\hline $\begin{array}{l}\text { Rental and leasing acti- } \\
\text { vities (N77) }\end{array}$ & 1308 & 2860 & 171 & 248 & 91 & 134 & 3639 & 4957 \\
\hline $\begin{array}{l}\text { Travel agency, tour ope- } \\
\text { rator reservation service } \\
\text { and related activities (N79) }\end{array}$ & 1222 & 914 & 326 & 549 & 38 & 60 & 5821 & 6224 \\
\hline
\end{tabular}

Note: UNWTO tourism industries

(1) NACE sections: B-N_S95_X_K (Total business economy; repair of computers, personal and household goods; except financial and insurance activities).

(2) NACE sections: H, I, J, L, M, N, S95.

(3) NACE sections: H49, H50, H51, I55, I56, N77 and division N79.

(4) NACE sections: H51, I55 and N79.

(5) NACE sections: H49, H50, I56, N77

Source: Own calculation based on data from Eurostat 
The tourism industries' shares of total turnover and value added at factor cost accounting for $6.51 \%$ of the turnover and $9.68 \%$ of the value added of the non-financial business economy in 2016. These figures very likely reflect the main features of many tourism industries - the higher share of micro, small and medium-sized enterprises and the level of part-time employment.

In Table 3 it is shown that the main part of these figures is generated by industries where the customers are likely to be a mix of tourists and non-tourists, e. g. "partially tourism". For instance, 219574 persons are employed in partially tourism that accounted $76.27 \%$ of turnover of tourism industries and $76.88 \%$ of total tourism's value added in 2016.

From 2008 to 2016 the sectors of tourism industries growth. Tourism industries (mainly and partially) showed a stronger growth than the total economy for all indicators concerned. Looking at those industries that are 'mainly tourism' the value added recorded a growth of $+57.09 \%$ between 2008 and 2016, the number of enterprises grew by $+58.25 \%$, the turnover by $+38.82 \%$ and the number of persons employed by $+11.18 \%$ (for the total economy the corresponding growth rates were $+37.6 \%$, $+21.44 \%,+13.2 \%$ and $-5 \%$ respectively)

\section{Analysis by subsectors}

The main part of the enterprises in the tourism industries operated in accommodation (NACE I55) and food and beverage serving activities (NACE I56): $9 \%$ and $44 \%$ respectively in 2016 (Table 3) and the number of persons employed in them accounted $53 \%$ of total one in tourism industries. However, in terms of turnover and value added, their share was much lower $(28.52 \%$ of turnover, $34 \%$ of value added).

The turnover and value added of passenger transport related industries (parts of NACE $\mathrm{H} 49$, H50, H51) represented $61.29 \%$ of the turnover for all tourism industries and $57.87 \%$ of the total value added of tourism industries: in 2016 over $90 \%$ of this share came from the subsector of land transport (NACE H49) which is respectively, $42 \%$ and $72 \%$ more than the figures from 2008.

Travel agencies, tour operators and other related activities (NACE N79) and Rental and leasing activities (NACE N77) recorded a turnover of 549 and 248 million euro in 2016, respectively, an increase by $68 \%$ and $45 \%$ compared to 2008. These activities represented $10 \%$ of the turnover in tourism industries, compared with a $8 \%$ share in value added at factor cost, $4 \%$ share in employment and 7.5 $\%$ in number of enterprises

\section{Driving Forces for Sustainable Tourism.}

Alongside an economic dimensions, sustainable tourism has an economic-social and ecological components due to it is known that if the one of three problems could be solved the other two need to be solved too. Table 4 presents the main driving forces for sustainable tourism and related to them social and ecological components. Part of the indicators used in it are taken from DPSIR framework.

Looking at the data in table it can be seen that capacity of beds in hotels and similar establishment over the past ten years (20082018) is relatively constant - about 0.05 bed per inhabitant. Results lead to the conclusion that no extra pressure on the environment is expected in near future but emerge the need for diversification of the tourist product to better economic performance.

According to latest Eurostat data, the number of trips made by different modes of transport shows that a major share of total trips is made by road transport $(93.14 \%$ in 2017 including $16.22 \%$ by bus), the share of bus transport decreases which is opposite of transport with a private car. It is noticed also a negative dynamic in trips made by train transport. This could have a negative impact on the environment. The Bulgarian government has to modernize and promote the use of rail transport which has a positive economic impact on national budget and rate of employment.

In 2018 Tourism generated $1.61 \%$ more jobs directly or 93026 jobs than 2017 (2.94\% of total employment) and its total contribution was 346794 jobs $(10.95 \%$ of total employment). The shares are rising but still could not reach the pre-crisis level from 2008 tourism's direct contribution was 104490 jobs (decrease of $11 \%$ compared to 2008) and total contribution was 422662 jobs (decrease of 18 $\%$ ). According to WTTC in 2019 Tourism will account for 93273 jobs directly and 347412 total jobs. This is forecast that direct jobs to grow by $2.75 \%$ average over the next ten years and reach $4.14 \%$ of total employment (121 953 jobs) and total jobs to grow by $1.33 \%$ average and to support 395690 jobs (13.46 
DONCHEVA D.

\%of total employment) by 2028. According to NSI the number of seasonal jobs in tourism are expected to decrease gradually from $19 \%$ of all persons employed in tourism in 2019 to 15
$\%$ in 2030 . The actual and expected increase of both a direct and total contribution of Tourism to employment will lead to rising incomes and living standards of the population.

Table 4. Driving forces for sustainable tourism of Bulgaria for period 2008-2018

\begin{tabular}{|c|c|c|c|c|c|c|c|c|c|c|c|}
\hline $\begin{array}{l}\text { Driving } \\
\text { Forces }\end{array}$ & 2008 & 2009 & 2010 & 2011 & 2012 & 2013 & 2014 & 2015 & 2016 & 2017 & 2018 \\
\hline \multicolumn{12}{|c|}{ 1. Number of beds in hotels and similar establishments by inhabitants (ratio) } \\
\hline & 0.04 & 0.04 & 0.04 & 0.04 & 0.04 & 0.04 & 0.04 & 0.05 & 0.05 & 0.05 & 0.05 \\
\hline \multicolumn{12}{|c|}{ 2. Number of trips by means of transport - \% of trips made by: } \\
\hline plane & $:$ & $:$ & $:$ & $:$ & 4.66 & 4.12 & 4.44 & 4.83 & 5.92 & 4.65 & $:$ \\
\hline road transport & $:$ & $:$ & $:$ & $:$ & 90.60 & 91.20 & 92.05 & 93.02 & 91.16 & 93.14 & $:$ \\
\hline $\begin{array}{r}\text { incl. bus, } \\
\text { coach } \\
\end{array}$ & $:$ & $:$ & $:$ & $:$ & 23.44 & 19.46 & 20.57 & 18.25 & 17.97 & 16.22 & $\therefore$ \\
\hline train & $:$ & $:$ & $:$ & $:$ & 4.75 & 4.68 & 3.51 & 2.12 & 2.92 & 2.21 & $:$ \\
\hline \multicolumn{12}{|c|}{ 3. Tourism-related employment (\% of total empl.) } \\
\hline & 4.38 & 4.93 & 5.14 & 5.47 & 5.40 & 5.34 & 5.23 & 5.14 & 5.36 & 6.11 & 6.03 \\
\hline \multicolumn{12}{|c|}{ 4. Total Tourism contribution to Employment ( $\%$ of total empl.) } \\
\hline & 12.58 & 11.54 & 10.47 & 10.08 & 9.73 & 10.76 & 10.73 & 9.96 & 10.50 & 10.75 & 10.95 \\
\hline \multicolumn{12}{|c|}{ 5. Household consumption expenditure on tourism (percentage of total) } \\
\hline $\begin{array}{l}\text { Food and } \\
\text { beverages }\end{array}$ & 20.4 & 18.8 & 19.6 & 19 & 18.4 & 18.5 & 19.1 & 19.4 & 19.5 & 19.2 & \\
\hline Transport & 15.8 & 16.4 & 15.9 & 15.4 & 15.9 & 15.2 & 14.8 & 15.1 & 14 & 13.9 & $:$ \\
\hline $\begin{array}{l}\text { Recreation and } \\
\text { culture }\end{array}$ & 7.9 & 7.3 & 7.6 & 7.1 & 6.7 & 7.1 & 7.5 & 7.6 & 7.8 & 7.9 & . \\
\hline $\begin{array}{l}\text { Restaurants } \\
\text { and hotels }\end{array}$ & 5.6 & 5.8 & 6 & 6.6 & 7.1 & 6.9 & 7.2 & 7.1 & 6.6 & 6.9 & $:$ \\
\hline \multicolumn{12}{|c|}{ 6. Tourism share of GDP, \% of GDP (direct) } \\
\hline & 3.35 & 3.15 & 2.88 & 2.90 & 2.85 & 3.07 & 3.10 & 2.77 & 3.36 & 3.09 & 3.11 \\
\hline \multicolumn{12}{|c|}{ 7. Total Tourism contribution to GDP, \% of GDP } \\
\hline & 13.65 & 12.37 & 10.97 & 10.77 & 10.39 & 11.47 & 11.61 & 10.76 & 11.25 & 11.53 & 11.71 \\
\hline
\end{tabular}

8. Number of tourism overnight stays in various types of accommodation, thousand number

\begin{tabular}{|c|c|c|c|c|c|c|c|c|c|c|c|}
\hline & 11802 & 9472 & 10565 & 12461 & 13451 & 14370 & 14078 & 13352 & 16151 & 17106 & 17749 \\
\hline \multicolumn{12}{|c|}{ 9. Bed-places in accommodation establishments - thousand number } \\
\hline & 277 & 287 & 284 & 283 & 301 & 302 & 314 & 322 & 328 & 349 & 336 \\
\hline
\end{tabular}

10. Net occupancy rate of bedrooms in hotels and similar accommodation (ratio)

\begin{tabular}{|l|l|l|l|l|l|l|l|l|l|l|}
42.67 & 32.96 & 37.25 & 43.99 & 44.67 & 47.52 & 44.80 & 41.41 & 49.20 & 49.05 & 52.89 \\
\hline
\end{tabular}

11. Total tourism gross fixed capital formation of tourism industries and other industries (\% of total investment)

\begin{tabular}{|l|l|l|l|l|l|l|l|l|l|l|}
\hline 8.19 & 5.82 & 5.94 & 6.20 & 6.22 & 6.51 & 6.86 & 7.25 & 7.16 & 7.46 & 7.40 \\
\hline
\end{tabular}

12. Expenditure to maintain / restore cultural and historical heritage, billion BGN

\begin{tabular}{|l|l|l|l|l|l|l|l|l|l|l|}
\hline 0.05 & 0.05 & 0.05 & 0.05 & 0.05 & 0.06 & 0.06 & 0.06 & 0.06 & 0.07 & 0.08 \\
\hline
\end{tabular}

Source: Own calculation based on data from NSI, Infostat, Eurostat, OECD, World bank, WTTC, SNA

: - does not apply

From 2008 to 2017 there is a slightly decrease in household expenditure on food and beverage and transport reached $19.2 \%$ and $14 \%$ relatively in 2017 . These results are logical given the above employment's results. In the other hand the share on household spending on restaurants and hotels increase to $7 \%$ in 2017 , whereas spending on recreation and culture stays relatively constant $(8 \%)$.

Increasing employment is linked to increasing production. The direct contribution of Tourism to GDP in 2018 was 3349.86 million BGN ( $3.11 \%$ of GDP), which is an increase of 3.81 $\%$ related to 2017. The figures for total 
contribution of Tourism to GDP are 12625.6 million BGN (11.71\% of GDP), an increase of $4.86 \%$ related to previous year. WTTC expected in 2019 the direct contribution to GDP to grow by $2.28 \%$ to 3530.38 million BGN and total contribution to reach to 13 325.6 million BGN. This is forecast that direct and total contribution to GDP to rise to 5 992.93 million BGN (3.66 \% of total GDP) and 21907.6 million BGN (13.39\% of total GDP) in 2028, relatively. The actual and expected increase of both a direct and total contribution of Tourism to GDP will lead to improving the country's economic activities and social welfare.

In 2018 compared to 2008 the number of overnight stays in various types of accommodation raised by $50 \%$ to 17748925 . It is also noticed an increase in the number of bed-places by $21 \%$ for the reference period. The net occupancy rate of bed-places reached $53 \%$ in 2018, an increase of $24 \%$ compared to 2008. From economic point of view, this has a positive impact on whole regional economy but from ecological point of view this may lead to an increase of pressure on the environment. This emerge the needs for diversification of tourist product and prolong the tourist season through the whole year which is associated with more investment. In 2018 total tourism gross fixed capital formation was 1567.29 million BGN (7.39\% of total investment). This is an increase by $9.04 \%$ compared to 2017 but a decrease of $20 \%$ compared to 2008). Tourism is expected to attract capital investment of 1653.22 million BGN (7.27\% of total investment) in 2019 and rise by $3 \%$ average over the next ten years to 2558.24 million BGN.

The government spending to maintain/restore cultural and historical heritage are important for the development of Tourism. Expenditure to maintain / restore cultural and historical heritage was 800 million BGN (3.34\% of total government individual expenditure) in 2018, $10.82 \%$ more than 2017 and $35.7 \%$ more than 2008. It is expected these spending to grow by $5 \%$ to reach $3.55 \%$ of total government individual expenditure in 2019 and is it forecast to rise to 126.657 million BGN in 2028, an increase of $2.86 \%$ average over the next ten years.

\section{CONCLUSIONS}

The overall comparison of the selected indicators for the evaluation of sustainable development of tourism in Bulgaria demonstrated that the development is quite stable.

The conducted analysis allows the author to formulate the following conclusions:

- The growth of Bulgarian tourism in the last ten years results in an increase of tourism's contribution to the development of the country. Tourism sector forms almost $12 \%$ of country's GDP, $11 \%$ of employment, over $28 \%$ of value added and over $7 \%$ of total investments for the reference period. This is forecast that Tourism sector will show positive trends in shares of country's GDP, employment and investments in the next ten years. That will lead to improving the living standard of tourismbased-population and economic growth;

- Bulgaria has a potential to develop an alternative forms of tourism - business, cultural, spa and eco, that will reduce seasonality dependence of the tourism and number of part-time employed and lead to diversification of tourist product. In the reference period, the country was established as a favorable tourist destination for meetings and congresses at international and national level due to a remarkable growth shown by visitors that came by professional purpose and also high share of total visitors traveled by other purpose;

- The country has enough number of accommodation beds and hotels. The main reason for unoccupied capacity is due to the seasonality of tourism in Bulgaria. Diversification of the tourist product and prolong the active season will lead to higher occupancy of accommodation establishment and hence increasing of economic performance;

- The key factor for developing of sustainable tourism is the good condition of the country's transport system. In the last decade the major road infrastructure was developed that result in changes in the number of trips made by different modes of transport. Data shows that both - Bulgarian and foreigners travelers prefer road transport due to easy access to different destinations. In the next years, it is important for Bulgaria to modernize and promote the use of rail transport which has a less harmful impact on the environment.

The assessment of economic dimensions of sustainable tourism in Bulgaria revealed that the tourism sector was driver for recovery of the economy from the financial crisis from 2008 and booster for regional and national prosperity, rising of living standard and well- 
being of the population. As Bulgaria is at its early stages of development of sustainable tourism the responsible authorities have to provide a favorable environment and business area for developing sustainable and competitive tourism and strive for "proecological" policy that will meet needs of present and future generations.

\section{REFERENCES}

1. Ministry of Tourism, National Strategy for Sustainable development of Tourism in Bulgaria, 2014-2030, 2017;

2. UNWTO, Tourism and the Sustainable Development Goals -Journey to 2030, 2017: 44, Available at: www.eunwto.org/doi/book/10.18111/9789284419 401;

3. Ministry of Tourism, National Strategy for Sustainable development of Tourism in Bulgaria, 2014-2030, 2017;

4. European Commission, European Tourism Indicator System, ETIS toolkit for sustainable destination management, 2016;

5. Ministry of Tourism, National Strategy for Sustainable development of Tourism in Bulgaria, 2014-2030, 2017: 27;

6. UNWTO, Tourism and the Sustainable Development Goals -Journey to 2030, 2017: 100-103, Available at: www.eunwto.org/doi/book/10.18111/9789284419 401;

7. Guerreiro, S., Seguro, P., Monitoring sustainability performance in the Portuguese tourism industry, Available at: http://www.15th-tourism-stats-

forum.com/pdf/Papers/

S2/2_2_Sustainable_ tourism indicators_monitoring_of_sustainability_pe rformance_in_the_ tourism_industry_in_Portugal.pdf

8. Ministry of Tourism, National Strategy for Sustainable development of Tourism in Bulgaria, 2014-2030, 2017: 3;

9. Ministry of Tourism, National Strategy for Sustainable development of Tourism in Bulgaria, 2014-2030, 2017: 83;

10.Jurigová, Z., Tučková, Z., Solenes, O., The impact of chosen economic indicators on tourism sustainability: case study of the Czech Republic and Norway. Journal of Security and Sustainability, 7(1): 113-121, 2017;

11.Daly, H., Beyond Growth: The Economics of Sustainable Development. Beacon Press, Boston, 1996;

12.Vojnovic, N., Knezevic, R., Economic and tourism indicators as a means of monitoring sustainable tourist: The case of inland Istria. UTMS Journal of Economics, 4 (2): 213230, 2013;

13.Rio, D., Nunes, L. M., Monitoring and evaluation tools for tourism destinations. Tourism Management Perspectives, 4: 6466, 2012

14.Oyola, M., Blancas, J. F., González, M., Caballero, R., Sustainable tourism indicators as planning tools in cultural destinations. Ecological Indicators, 18: 659-675, 2012;

15.Franzoni, S., Measuring the sustainability performance of the tourism sector. Tourism Management Perspectives, 16:22-27, 2015;

16.European Union, European Tourism Indicator System TOOLKIT for Sustainable Destinations. DG Enterprise and Industry, 2013;

17. World Tourism Organization, Indicators of Sustainable Development for Tourism Destinations: A Guidebook. World Tourism Organization, Spain, 2004;

18.Kristensen, P., The DPSIR Framework, 2004, Available at: https://wwz.ifremer.fr/dce/content/downloa d/69291/913220/.../DPSIR.pdf;

19. OECD, Environmental Indicators: Towards sustainable development, 2001, Available at:

https://www.oecd.org/site/worldforum/337038 67.pdf;

20.Khuntia, N., and Mishra, J. M., Economic and Environmental Aspects of Sustainable Tourism Development - A Conceptual Study. Atna, J Tour Stud, 9(1): 15-28, 2014;

21.Gardetti, M. A., Torres, A. L., Sustainability in Hospitality: How innovative hotels are transforming the industry. Greenleaf Publishing Limited, Shefield, 2016;

22.UNEP \& UNWTO, Making Tourism More Sustainable. A Guide for Policy Makers, 2005:24, Available at: http://www.unep.fr/shared/publications/pdf/ DTIx0592xPA-TourismPolicyEN.pdf;

23.UNSD, Eurostat, OECD and UNWTO, 2008 Tourism Satellite Account: Recommended Methodological Framework (TSA:RMF 2008). The document is available on the Eurostat website;

24.Statistical Framework for Measuring Sustainable Tourism - Consultation Draft, , February 2018, available at: http://cf.cdn.unwto.org/sites/all/files/pdf/sfmst_feb.pdf

25. UNWTO Committee on Tourism Statistics, Methodological work on measuring the 
sustainable development of tourism. Office for Official Publications of the European Communities, Luxembourg, 2006;

26.https://unstats.un.org/unsd/nationalaccount/ sna.asp

27.http://www.nsi.bg/en

28.https://infostat.nsi.bg/infostat/pages/externa $1 / \operatorname{login} . j s f$ 29.https://data.worldbank.org/

30.https://ec.europa.eu/eurostat/data/database

31.https://stats.oecd.org/

32.https://www.wttc.org/economicimpact/country-analysis/country-reports/

33.OECD, Tourism Trends and Policies. OECD Publishing, Paris, 2018, Available at: http://dx.doi.org/10.1787/tour-2018-en 